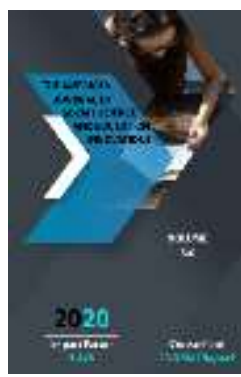

\title{
The Power Of The Mysterious Inversion In Literary Books
}

\author{
Tilavova Malika Mamaraimovna \\ Master Degree Student, Faculty Of Foreign Languages, Jizzakh State Pedagogical Institute, \\ Uzbekistan
}

\begin{abstract}
Journal Website: http://usajournalshub.c om/index,php/tajssei

Copyright: Original content from this work may be used under the terms of the creative commons attributes 4.0 licence.
\end{abstract}

\section{ABSTRACT}

Language is a great blessing given to humanity, literary devices that make the language shiny, colorful, meaningful, an inversion literary device that enhances clarity with formality and emphasis, its importance and important functions, types, uses and the Uzbek writer Tahir Malik skillfully used inversion in "Samum" and skillfully interpreted the words of the inversion phenomenon in the work and skillfully conveyed it to the reader, and words in literary books the features of magic enhancement, translation studies on inversion, and their importance are covered in detail in this article.

\section{KEYWORDS}

Literary devices, simile, metaphor, alliteration, inversion, an anastrophy, , locative inversion, directive inversion, quotative and copular inversions, Tohir Malik, Samum, " A steppe of false hopes", Seonaid Beckwich, literary technique.

\section{INTRODUCTION}

Life is a great gift from God to all human beings. The happiness of enjoying the blessings of life by talking is given only to humanity. In this case language is the key element. Only through language do we show all our talents. There are a variety of literary devices that make our language beautiful, convey it fully and clearly to the listener. Every nation uses these literary devices to express its language in a vivid, clear, and understandable way. These literary devices include: simile, metaphor, imagery, allegory, alliteration, inversion and etc.

Let's start my article with an initial understanding of the power of inversion and 
its importance. Every speaker, whether he has a certain profession, whether she is an ordinary housewife, even a young child, of course, they use inversion in their daily lives. But someone uses it skillfully in conversation, then someone else uses it unknowingly. Initially, we use the inversion in our family circle, kindergarten or elementary school periods. Only later will we realize that it is a scientific term inversion. For instance, in my childhood, when my mother said, "Yesterday your best friend I saw," my teacher said, "An excellent decision you made there," or in my textbook, "Tomorrow will come the decision," in these sentences, I have already encountered an inversion event. Maybe I used it myself in my following remarks. They are: "How amazing this is" or "Shocked, I was" and so on. My homeland is Uzbekistan. Just like me, my countrymen and everyone has certainly used and will continue to use such statements in their lives.

What is inversion? Where does it occur? When and how do we use inversion? How important is inversion in our lives? Let's take a brief look at the questions and talk about the answers to these questions, the work done, the research done.

In English, the traditional word order of a statement is subject + verb. Never do we change the order except when asking a question. Or do we? If you listened closely, you may have noticed that my statement beginning with the word "never" failed to follow the usual order. I put the auxiliary verb "do" before the subject "we" and the main verb "change" after the subject. Using this word order in statements is called "inversion."

"We use inversion to add emphasis to statements and variety to our writing. Inversion can "make[s] our sentence[s] sound surprising or striking or unusual," writes Seonaid Beckwich. She is founder of the website Perfect-English-Grammar.com. But inversion is not for everyday speech. English speakers use it in formal statements, and most often in writing, such as in essays and works of literature. And, it is only done with some words and phrases.

Inversion, as a literary medium, means changing the syntactically correct order of subjects, verbs, and things in a sentence. This type of inversion is also called an anastrophy, from the Greek "reverse". English has a fairly strict order of sentence structure, usually subjectverb object (many other languages allow for more ordering of parts of speech). For example, to say "I saw a ship yesterday" is syntactically correct. The reverse side of this sentence could be "Yesterday I saw a ship" or "Yesterday I saw a ship".

In linguistics, inversion is any of several grammatical constructions where two expressions switch their canonical order of appearance, that is, they invert. There are several types of subject-verb inversion in English: locative inversion, directive inversion, copular inversion, and quotative inversion. The most frequent type of inversion in English is subject-auxiliary inversion in which an auxiliary verb changes places with its subject; it often occurs in questions, such as Are you coming?, with the subject you is switched with the auxiliary are. In many other languages, especially those with a freer word order than English, inversion can take place with a variety of verbs (not just auxiliaries) and with other syntactic categories as well.

Inversion as a stylistic device is always sensemotivated. There is a tendency to account for inversion in poetry by rhythmical considerations. Inverted word-order is one of the forms of emphatic constructions. What is generally called traditional word-order is nothing more than unemphatic construction. Emphatic constructions have been regarded as nontypical structures and are considered as violations of the regular word-order in the sentence. But in practice these structures are 
as common as the fixed or traditional wordorder structures. Therefore inversion must be regarded as an expressive means of the language having typical structural models.

Word-order is a crucial syntactical problem in many languages. Stylistic inversion aims at attaching logical stress or additional emotional colouring to the surface meaning of the utterance. Thereforeore a specific intonation pattern is the inevitable satellite of inversion.

\section{MATERIALS AND METHODS}

Stylistic inversion in Modern English should not be regarded as a violation of the norms of standard English. It is only the practical realization of what is potential in the language itself.

The following patterns of stylistic inversion are most frequently met in both English prose and English poetry.

1. The object is placed at the beginning of the sentence (see the example above).

2. The attribute is placed after the word it modifies (postposition of the attribute). This model is often used when there is more than one attribute, for example: "With fingers weary and worn..." "Once upon a midnight dreary..."

3. a) The predicative is placed before the subject, as in "A good generous prayer it was." (Mark Twain)

b) the predicative stands before the linkverb and both are placed before the subject, as in "Rude am I in my speech..." (Shakespeare)

4. The adverbial modifier is placed at the beginning of the sentence:

"Eagerly I wished the morrow." (Poe)
"My dearest daughter, at your feet I fall." (Dryden)

"A tone of most extraordinary comparison Miss Tox said it in." (Dickens)

5. Both modifier and predicate stand before the subject:

"In went Mr. Pickwick." (Dickens) "Down dropped the breeze..." (Coleridge)

These five models comprise the most common and recognized models of inversion. However, in modern English and American poetry there appears a definite tendency to experiment with the word-order to the extent which may even render the message unintelligible. In this case there may be an almost unlimited number of rearrangements of the members of the sentence.

When writers use inversion as a literary technique, they purposefully reword phrasing in sentences to contrast the traditional organization in order to achieve a desired affect on the audience. Let's see example of Inversion:

Traditional order: The short woman asked for assistance while trying to reach items from the top shelf.

Inversion: The woman of small stature asked for assistance while trying to reach items from the top shelf.

Explanation: Typically when a writer uses adjective or descriptors, they are placed before the noun; however, by using inversion the writer breaks from the pattern to make a more interesting sentence.

Now modern examples of Inversion: The wellknown character, Yoda, from Star Wars speaks using inversion and is famously known for his manner of speaking. By having him speak in a manner of inversion, it highlights his intelligence and allows for his wise words to 
stand out to the audience. Here are some of Yoda's famous lines that exemplify the technique of inversion: "When nine hundred years old you reach, look as good you will not." "Truly wonderful, the mind of a child is."

The study of trends in the translation of inversions in English seems to be an urgent task, because - in the era of active interethnic relations - indirect, that is, the lack of understanding of intercultural and interpersonal communication in direct (oral) or indirect (reading literature) communication of speakers of different languages due to mistranslation can help. As an example of the study of inversion translations, 6 translations of Lewis Carol's "Alica in the Wonderland" and three translations of D. H. Lawrence's "Lady Chatterley's Lover" and other works can be cited. Russian writers P. V. Kulikover, R.D. Levin, I. Jukova, M. Kan and others made significant contributions to the translation of these works.

\section{RESULT AND DISCUSSION}

Tohir Malik was an Uzbek novelist and story writer. He was awarded Uzbek National Writer in 2000. He was author of "World of Demons ", "Sky”, “ Corpses do not speak" and etc. Samum is one of his famous book. "A Steppe of False Hopes " is the first book of Samum. In this work by Tahir Malik, I would like to give an example by translating into English the sentences based on the phenomenon of inversion. As the reader reads the work with great interest, the writer skillfully uses inversion.

1. “ Sen ularning sovuniga kir yuvmagansan. Odam bo'laman, desang , o'sha idoraning daraxtiga qo'ngan chumchuqni ham nazaringdan qochirma!" Bo'ron “ Bo'ldi, jo'na”, deganday qo'l siltab qo'ydi. [ Tohir Malik,
Yolg'on umidlar dashti, birinchi kitob Samum, 31 b]

" Didn't wash you the laundry in their soap. Should you want to be a man, don't miss even a sparrow that landed on the tree in that office!" Buran shook his hand as if to say " Enough, go". [ Tohir Malik, A steppe of false hopes', first book Samum, $30 \mathrm{p}$ ]

In turn, conditional sentences can also be inverted. Sometimes they are inverted to sound more formal. In these kinds of sentences the conditional word if is omitted and the auxiliary word is put before the subject of the sentence and that's why these kinds of sentences are much like question forms. As in :

If you should need my help, please contact me

\section{Should you need my help,please contact me.}

2. G'irrom “ zona "da Bo'ron bilan birinchi marta uchrashganida tirik qolishiga amin edi. Hechqachon o'sha qorong'u kechada o'limi sari qadam qo'yganini hayoliga ham keltirmasdi u . [ Tohir Malik, Yolg'on umidlar dashti, birinchi kitob Samum, 31b ]

Girrom was confident he would survive when he first met Buran in the "zone ". Never had he idea that he had stepped to his death on that dark night. [ Tohir Malik, A steppe of false hopes, first book Samum, $31 \mathrm{p}$ ]

As a rule, inversion is used in this sentence with special devices and expressions such as hardly, scarcely, no sooner, never, nothing, not only ,on no account, under no circumstances, in no way, at no time.

3. “ Men bir ko'rishda sevib qolgan, qanchalar go'zal ayol edi u !" hayoliga keltirdi Bo'ron. 
"Such a beautiful woman was she that I fell in love at first site! " thought Buran. [ Tahir Malik, A steppe of false hopes, first book Samum , 33 p]

As a rule, inversion is used after the word such in the sentence.

4. Xonaga katta leytenant libosidagi Shuhrat kirib keldi-da, G'ayratga quchoq ochib yaqinlashdi.

Into the room came Shuhrat, dressed as a senior lieutenant and approached Gayrat with a hug. [ Tohir Malik, A steppe of false hopes, first book Samum, $37 \mathrm{p}$ ]

Here you can see, as a rule, inversion is used after place names in the sentence.

\section{5. "Mana biz kutgan ish bo'yicha hisobot"-} dedi leytenant boshini mag'rur ko'tarib.

" Here is the report on the case we expected. "-said the lieutenant raising his head proudly. [ Tohir Malik, " A steppe of false hopes ",first book Samum, 43 p ]

As a rule, inversion is used after the words here and there in the sentence.

6. “ Guruch ko'rmaksiz bo'Imaydi, yana bittasini maqtadingiz-ku? Ikkovi birga o'qishganda." - dedi podpolkovnik Narziyev. [ Tohir Malik, Yolg'on umidlar dashti, birinchi kitob Samum, $61 \mathrm{~b}$ ]

"It is impossible not to be the rice without waste, did you praise another one? The two studied together."- said Lt. Col. Narziyev.

There are are also some uses of inversion in direct speech. Inversion is used in sentences in direct speech with verbs such as said, asked.
7. Sevgi o'zini shu qadar omadli va baxtli his etdiki, hatto yoniga kim chorlayotganini bilolmay ham qoldi. [ Tohir Malik, Yolg'on umidlar dashti, birinchi kitob Samum, 53b]

So happy and lucky felt Love, that she didn't even know who was calling her.

Here, inversion is used with this construction so + adjective in the sentence.

8. “ Meni yo'qotsangiz, izlab yurmang. Hech qayerdan topa olmaysiz..."- dedi Axloq. [ Tohir Malik, Yolg'on umidlar dashti, birinchi kitob Samum, 55 b]

“ Lose you me, don't look for me. Won't find you me anywhere..." -said Morality.

Note: the part of conditional sentences

9. . Hozir o'rni emas, lekin bunday jazoning vaqti, o'rni kelishi tayin. Agar siz bo'Imaganizda edi, men bu imtihondan o'tmagan bo'lardim [ Tohir Malik, Yolg'on umidlar dashti, birinchi kitob Samum, 46 b]

Now is not the place, but the time and place of such punishment is certain. Had it not been for you, I would not have passed that exam.

Here, inversion is used with this construction Had in not been for ..., would have $+V_{3}$ in the sentence.

All of the above examples help the reader who is reading the book to fall into that environment, to feel like a participant in the same situation by emphasizing the words.

And also the use of inversion is an important stylistic technique in both prose and poetry. It allows for the writer to organize thoughts in an 
interesting way in order to emphasis certain ideas to the reader. In addition to focusing the attention to certain words or phrases, by using a different order than the typical sentence structure, it creates a certain rhythm to the piece of literature.

So, in conclusion, the correct use of the inversion literary device in its place is an important factor and clearly and accurately conveying your goal.

Inversion happens in English for emphasis, dramatic purpose or formality.

After learning inversion, we will have the following options:

1. Understanding the language in the original As you can see, many of the use cases are both literary, formal and spoken English, so you need to have knowledge of inversion to understand what the author specifically means.

2. Vivid and rich natural speech

If you want to overcome the plateau effect and mid-level crisis and reach a new level, clearly convey your thoughts and emotions, then enrich your speech with sentences with inversion.

3. International exams

\section{CONCLUSION}

Inversion is the golden key that will open up extra points for you on exams. All, without exception, aids for preparing for FCE, CAE, CPE, IELTS consider this topic and take it to a separate place. If your essay or oral answer contains an appropriate, meaningful, correctly formulated sentence, you are guaranteed a plus on the exam.

\section{REFERENCES}

1. https://www.thoughtco.com/inversiondefinition-1209968 Cambridge Advanced Learners' Dictionary, 3rd edition.

2. Longman Dictionary of Contemporary English, 5th edition

3.

http://dictionary.cambridge.org/grammar/b ritish-grammar/word-order-andfocus/inversion

4. http://usefulenglish.ru/miscellany/inversion

5. www.learn-englishtoday.com/lessons/lesson_contents/verbs/i nversion.html

6. Chung 2002 - Chung Ch. Mixed Functional Properties in English Stylistic Inversion. Dongseo University, $2002 . \quad-$ http://cslipublications.stanford.edu/HPSG/2 /chung-inv1-pn.pdf

7. Culicover P.W., Levine R.D. Natural Language \& Linguistic Theory. Kluwer Academic Publishers, 2001.

8. Fowler 1908 - Fowler H.W. The King's English, 2nd ed. 1908. http://www.bartleby.com/116/303.html

9. Lawrence D.H. Lady Chatterley's Lover, 2000. - http://www.lib.ru/INPROZ/ CHATER/lady.txt

10. Lewis Carroll. Alice's adventures in Wonderland. http://www.lib.ru/CARROLL/alice.txt

11. Wilson 1993 - Wilson K.G. The Columbia Guide to Standard American English. Columbia University Press, 1993. Inversion in questions. http://www.bartleby.com/68/10/3411.html 
The American Journal of Social Science and Education Innovations (ISSN - 2689-100x)

Published: November 30, 2020 | Pages: 592-598

Doi: https://doi.org/10.37547/tajssei/Volume02Issue11-102

2020: $5 \cdot 525$

12. 2001.

http://www.lib.ru/CARROLL/alisa_yun.txt

13. Tohir Malik . A Steppe of False Hopes [

First book of Samum ].- Tashkent 2018. 